\title{
FUNGSI NOTARIS DALAM PEMERIKSAAN IDENTITAS PENGHADAP TERHADAP AUTENTISITAS AKTA DIHUBUNGKAN DENGAN ASAS KEHATI-HATIAN
}

\author{
Dea Derika \\ Fakultas Hukum Magister Kenotariatan Universitas Islam Bandung \\ deaderika171717@gmail.com \\ DOI : https://doi.org/ 10.29313/shjih.v18i2.6514
}

\begin{abstract}
Abstrak
Notaris dalam menjalankan fungsinya, dituntut untuk mengenali Penghadap guna mencegah adanya pemalsuan identitas sehingga dibutuhkan asas kehati-hatian. Dari hasil penelitian disimpulkan bahwa autentisitas akta Notaris dihubungkan dengan asas kehati-hatian yakni memastikan terpenuhinya unsur pembuktian formill akta berdasarkan UUJN dan hukum pembuktian perjanjian serta syarat sahnya suatu perjanjian yang diatur dalam Hukum Perdata. Fungsi Notaris dalam pemeriksaan identitas penghadap berdasarkan UUJN yakni melakukan pengenalan penghadap, memastikan kebenaran identitas penghadap, dan membuat akta berdasarkan UUJN sebagaimana Pasal 39, Pasal 40 UUJN tentang syarat-syarat yang harus dipenuhi penghadap. Fungsi Notaris dalam pemeriksaan identitas penghadap berdasarkan UUJN dihubungkan dengan asas kehati-hatian yakni menjamin autentisitas akta sehingga Notaris dituntut untuk cermat dan teliti dalam pemeriksaan identitas penghadap sebagaimana Pasal 16 ayat (1) huruf (a) UUJN, serta ditindaklanjuti dalam Pasal 2 ayat (2) Peraturan Menteri Hukum Dan Hak Asasi Manusia Nomor 9 Tahun 2017 tentang Penerapan Prinsip Mengenali Penguna Jasa Bagi Notaris.
\end{abstract}

Kata Kunci: Fungsi Notaris, Prinsip Kehati-hatian, Akta Notaris

\begin{abstract}
In carrying out its function, notaries are required to identify the Appellants in order to prevent identity falsification so that the principle of caution is needed. The final conclusion is The authenticity of notary deeds is linked to the principle of prudence, namely ensuring the fulfillment of the proof of form of deeds based on UUJN and the law of proof of agreement as well as the validity of an agreement regulated in Civil Law. The function of the notary in examining the identity of the applicant based on UUJN is to identify the face of the applicant, ensure the correctness of the identity of the applicant, and make deeds based on UUJN as referred to in Article 39, Article 40 of UUJN regarding the conditions that must be met by the applicantThus, the function of the Notary in examining the identity of tappers based on UUJN is connected with the principle of prudence, namely ensuring the authenticity of deeds so that Notaries are required to be careful and thorough in examining the identity of tappers as referred to in Article 16 paragraph (1) letter (a) UUJN, and followed up in Article 2. paragraph (2) Regulation of the Minister of Law and Human Rights Number 9 of 2017 concerning Application of the Principles of Recognizing Service Users for Notaries.
\end{abstract}


Keywords: Notarial Fuction, The Precautionary Principle, Notarial Deed.

\section{A. PENDAHULUAN}

Notaris adalah pejabat umum yang berwenang membuat akta dan kewenangan lainnya sebagaimana dimaksud dalam Pasal 1 angka (1) UndangUndang Nomor 2 Tahun 2014 tentang Perubahan atas Undang-Undang Nomor 30 Tahun 2004 tentang Jabatan Notaris (UUJN). ${ }^{1}$ Dalam Pasal 15 UUJN, menjelaskan bahwa kewenangan Notaris sebagai penjabaran Pasal 1 angka (1) meliputi kewenangan membuat akta, mengesahkan salinan dari keaslian surat, melakukan penyuluhan hukum terkait pertanahan dan membuat akta risalah lelang. Selain itu, Notaris berkewajiban bertindak jujur, seksama, mandiri, tidak berpihak, dan menjaga kepentingan pihak terkait dalam perbuatan hukum sehingga akta yang dibuatnya harus memberikan kepastian hukum. ${ }^{2}$

Dalam hal pengecekkan identitas penghadap terhadap autentisitas akta, maka Notaris wajib meminta dokumen atau surat-surat yang diperlukan untuk dituangkan di dalam akta. Dokumen yang wajib diminta oleh Notaris untuk dilampirkan salinannya dalam Minuta Akta (asli Akta Notaris) adalah tanda pengenal atau Kartu Tanda Penduduk (KTP). Notaris harus memastikan penghadap menggunakan identitas asli dalam akta yang akan dibuat. ${ }^{3}$ Selain itu, terdapat beberapa persyaratan yang harus dipenuhi penghadap dalam pembuatan akta yaitu penghadap berumur paling sedikit 18 (delapan belas) tahun atau telah menikah dan cakap melakukan perbuatan hukum, Penghadap

\footnotetext{
${ }^{1}$ Hartanti Silihandari \& Nisya Rifiani, Prinsip-Prinsip Dasar Profesi Notaris (Yogyakarta: Dunia Cerdas, 2013), hlm. 2-3.

${ }^{2}$ Ibid, Pasal 16 ayat (1).

${ }^{3}$ Rahmad Hendra. Tanggung Jawab Notaris Terhadap Akta Autentik yang Penghadapnya Mempergunakan Identitas Palsu. Jurnal Ilmu Hukum, vol. 2, no. 2. Universitas Riau, Kota Pekanbaru, 2012, hlm. 2.
} 
harus dikenal oleh Notaris atau diperkenalkan kepadanya oleh 2 (dua) orang saksi pengenal yang berumur paling sedikit 18 (delapan belas) tahun atau telah menikah dan cakap melakukan perbuatan hukum atau diperkenalkan oleh 2 (dua) penghadap lainnya, dan pengenalan dinyatakan secara tegas dalam akta. ${ }^{4}$

Dalam Pasal 40 UUJN, menjelaskan bahwa setiap akta yang dibacakan oleh Notaris dihadiri paling sedikit 2 (dua) orang saksi, kecuali peraturan perundang-undangan menyatakan lain, saksi harus memenuhi syarat yaitu berumur paling sedikit 18 (delapan belas) tahun atau telah menikah, cakap melakukan perbuatan hukum, mengerti bahasa yang digunakan dalam akta, dapat membubuhkan tanda tangan atau parah, dan tidak mempunyai hubungan perkawinan atau hubungan darah dalam garis lurus ke atas atau ke bawah tanpa pembatasan derajat dan garis ke samping sampai dengan derajat ketiga dengan Notaris atau para pihak. Selain itu, saksi harus dikenal oleh Notaris atau diperkenalkan kepada Notaris atau diterangkan tentang identitas dan kewenangannya kepada Notaris oleh penghadap. Pengenalan atau pernyataan tentang identitas dan kewenangan saksi dinyatakan secara tegas dalam akta. ${ }^{5}$ Apabila persyaratan pembuatan akta tersebut tidak terpenuhi, maka autentisitas akta tersebut hanya mempunyai kekuatan pembuktian sebagai akta di bawah tanda tangan. ${ }^{6}$

Berdasarkan hal di atas, maka Notaris dalam menjalankan fungsinya haruslah dapat mengenal para penghadap dalam pembuatan akta. Notaris harus meneliti semua fakta yang relevan dalam pertimbangannya berdasarkan undang-undang dan Kode Etik Notaris. Selain itu, Notaris juga harus memeriksa semua kelengkapan dan keabsahan alat bukti atau dokumen yang diperlihatkan kepada Notaris, serta mendengar keterangan atau pernyataan para penghadap wajib dilakukan sebagai dasar pertimbangan untuk dituangkan di dalam akta. Setelah itu, dilakukan pembacaan akta kepada pihak penghadap.

${ }^{4}$ Ibid, Pasal 39.

${ }^{5}$ Ibid. Pasal 40.

${ }^{6}$ Ibid. Pasal 41. 
Pembacaan akta penting dilakukan artinya agar para pihak yang menandatangani dan menyaksikan lahirnya akta tersebut benar-benar sepenuhnya sadar akan hal-hal yang diperjanjikan dan dinyatakan serta mengetahui akibat-akibat hukumnya. ${ }^{7}$ Hal ini dilakukan agar tidak terjadi kesalahan dalam pembuatan akta autentik sehingga tidak menimbulkan permasalahan hukum ke depannya. Apabila Notaris kurang teliti dalam memeriksa fakta-fakta penting, maka Notaris dalam menjalankan fungsinya sebagai pembuat akta bertindak tidak hati-hati. ${ }^{8}$

Asas kehati-hatian adalah suatu asas yang menyatakan bahwa Notaris dalam menjalankan fungsi dan jabatannya wajib berhati-hati dalam rangka melindungi kepentingan masyarakat yang dipercayakan padanya. Tujuan penerapan asas kehati-hatian adalah agar Notaris selalu dalam rambu-rambu atau Batasan-batasan yang benar berdasarkan Kode etik dan UUJN. Berlakunya asas kehati-hatian ini diharapkan agar kepercayaan masyarakat terhadap Notaris tetap tinggi sehingga masyarakat bersedia dan tidak ragu-ragu menggunakan jasa Notaris. ${ }^{9}$

Penerapan asas kehati-hatian oleh Notaris dalam pengecekan identitas penghadap terhadap autentisitas akta dapat dilakukan dengan pengenalan terhadap penghadap berdasarkan identitasnya yang diperlihatkan kepada Notaris, menanyakan dan mendengarkan serta mencermati keinginan atau kehendak para pihak tersebut dengan tanya jawab, memeriksa bukti surat yang berkaitan dengan keinginan atau kehendak para pihak tersebut, memberikan saran dan membuat kerangka akta untuk memenuhi keinginan atau kehendak para pihak tersebut, memenuhi segala teknik administrasi pembuatan akta

${ }^{7}$ Freddy Haris \& Leny Helena, Notaris Indonesia (Jakarta: Lintas Cetak Publishig, 2017). hlm.77.

${ }^{8}$ M. Luthfan Hadi Darus, Hukum Notariat dan Tanggung Jawab Jabatan Notaris (Yogyakarta: UII Press, 2017), hlm. 25.

${ }^{9}$ Rahaman, Fikri A. Penerapan Prinsip Kehati-hatian Notaris dalam Mengenal para Penghadap, Tesis, Universitas Islam Bandung, 2018, hlm. 54. 
Notaris, seperti pembacaan, penandatanganan, memberikan salinan, dan pemberkasan untuk minuta, melakukan kewajiban lain yang berkaitan dengan pelaksanaan tugas jabatan Notaris. ${ }^{10}$

Dalam Peraturan Menteri Hukum dan Hak Asasi Manusia Republik Indonesia Nomor 9 Tahun 2017 tentang Penerapan Prinsip Pengguna Jasa bagi Notaris menjelaskan bahwa Notaris berkewajiban untuk lebih teliti dan hatihati dalam mengenal para penghadap, baik memeriksa kelengkapan dan keaslian dokumen yang diperlihatkan, Notaris juga harus hati-hati apakah transaksi yang akan di buat dihadapan Notaris merupakan hasil pencucian uang atau bukan. Notaris harus melakukan identifikasi dan verifikasi data pengguna jasa secara menyeluruh yakni hingga kebenaran materill. Kewajiban menerapkan ketelitian dan hati-hati terhadap penghadap dilakukan pada saat Notaris meragukan kebenaran indentitas dan keterangan yang dilaporkan penghadap. $^{11}$

Berdasarkan uraian di atas, tentunya menimbulkan pertanyaan bagi peneliti bahwa jika Notaris menjalankan fungsinya dengan asas kehati-hatian berdasarkan Undang-Undang Jabatan Notaris terhadap pengecekkan identitas palsu dan keterangan yang diberikan penghadap, maka bagaimana autentisitas akta yang dibuat Notaris serta pertanggungjawaban Notaris terhadap akta yang terdapat identitas palsu penghadap ketika terjadi permasalahan hukum yang mengakibatkan Notaris akan dipanggil dan dimintai keterangannya atas akta yang dibuatnya.

Berdasarkan latar belakang masalah penelitian diatas, peneliti dalam hal ini mengidentifikasikan masalah sebagai berikut: Pertama, Autentisitas akta yang dibuat oleh Notaris dihubungkan dengan asas kehati-hatian dalam melaksanakan fungsi, Notaris. Kedua, fungsi Notaris dalam pemeriksaan

${ }^{10}$ M. Lutfan Hadi Darus, Hukum Notariat dan Tanggung jawab Jabatan Notaris (Yogyakarta: UII Pres, 2017), hlm. 39.

${ }^{11}$ Pasal 2 ayat (4), Peraturan Menteri Hukum dan Hak Asasi Manusia Nomor 9 Tahun 2017 tentang Penerapan Prinsip Mengenali Pengguna Jasa Bagi Notaris. 
identitas penghadap dihubungkan dengan tugas dan wewenang Notaris berdasarkan Undang-Undang Nomor 2 Tahun 2014 tentang Perubahan atas Undang-Undang Nomor 30 Tahun 2004 tentang Jabatan Notaris.

\section{B. METODE PENELITIAN}

Metode Penelitian yang digunakan adalah metode penelitian hukum normatif. Metode penelitian hukum normatif digunakan untuk untuk meneliti dan mengkaji data-data sekunder yang berkaitan dengan fungsi notaris dalam pemeriksaan identitas penghadap terhadap autentisitas akta dengan menggunakan asas kehati-hatian dalam UUJN. Spesifikasi/sifat penelitian ini adalah deskriptif analitis yang diharapkan memperoleh gambaran secara rinci dan sistematis tentang permasalahan yang diteliti. Penelitian ini pada umumnya bertujuan untuk mendeskripsikan secara sistematis, faktual, dan akurat terhadap suatu populasi atau daerah tertentu. Penelitian ini diharapkan memberi gambaran secara rinci, sistematis dan menyeluruh mengenai peraturan perundang-undangan yang berlaku, dikaitkan dengan teori-teori hukum dan praktek pelaksanaan hukum yang positif.

\section{PEMBAHASAN}

I. Autentisitas Akta Yang Dibuat Notaris Dihubungkan Dengan Asas Kehati-hatian Dalam Melaksanakan Fungsi Notaris

Akta autentik merupakan suatu akta yang didalam bentuk yang di tentukan oleh Undang-Undang atau di hadapan pegawai-pegawai umum yang berkuasa untuk itu di tempat dimana akta di buatnya sebagaimana dijelaskan dalam Pasal 1868 KUHPerdata. Bahwa ada 3 (tiga) unsur ensensial agar terpenuhinya syarat formal suatu akta autentik, sebagai berikut: ${ }^{12}$

1. Di dalam bentuk yang ditentukan oleh Undang-Undang;

2. Dibuat oleh dan di hadapan Pejabat Umum;

\footnotetext{
${ }^{12}$ Irwan Soerodjo, Kepastian Hukum Hak Atas Tanah di Indonesia (Surabaya: Arkola, 2003), hlm. 148 .
} 
3. Akta yang dibuat oleh atau di hadapan pejabat umum yang berwenang untuk itu dan di tempat di mana akta itu dibuat.

Notaris sebagai pejabat umum yang membuat akta autentik, bertanggungjawab atas perbuatannya sehubungan dengan pekerjaannya dalam membuat akta. Ruang lingkup pertanggung jawaban Notaris meliputi kebenaran formil atas akta yang dibuatnya, baik secara perdata maupun pidana sebagaimana telah dijelaskan dalam bab sebelumnya.

Menurut ketentuan yang tertuang dalam Pasal 16 ayat (1) huruf (m) UUJN, menjelaskan dengan jelas bahwa Notaris wajib membacakan akta yang dibuatnya di hadapan penghadap serta dihadiri sekurang-kurangnya dua orang saksi, atau dihadiri empat orang saksi khusus untuk pembuatan akta wasiat, sehingga dengan kata lain hanya Notaris yang dapat membacakan isi akta di hadapan penghadap sesuai atas apa yang tertuang dalam UUJN. Selanjutnya pengaturan tentang pembacaan akta Notaris diatur dalam Pasal 16 ayat (7) UUJN, merupakan Pasal pengecualian terhadap pembacaan akta Notaris dengan syarat penghadap telah membacanya sendiri, mengetahuinya, serta memahami isi dari akta yang akan dibuat, tetapi dalam pasal tersebut tidak menjelaskan secara eksplisit mengenai peran staf Notaris dalam pembacaan akta di hadapan para penghadap, yang kemudian menjadi alasan oleh Notaris untuk tidak membacakan akta di hadapan penghadap.

Penjelasan Undang-Undang Nomor 2 Tahun 2014 tentang Perubahan atas Undang-Undang Nomor 30 Tahun 2004 tentang Jabatan Notaris, penjelasan terhadap Pasal 16 ayat (1) huruf (m) bahwa Notaris harus hadir secara fisik dan menandatangani Akta di hadapan penghadap dan saksi. Serta dalam Pasal 16 ayat (8) menjelaskan bahwa "Pengecualian tersebut dikecualikan terhadap pembacaan kepala akta, komparasi, penjelasan pokok akta secara singkat dan jelas, serta penutup akta". Sehingga kemudian implikasi dari tidak dilaksanakannya apa yang tertuang dalam pasal-pasal tersebut di atas berakibat pada kekuatan pembuktian akta yang dibuat oleh Notaris sebagaimana tertuang dalam ketentuan Pasal 16 ayat (9) UUJN, yaitu "Akta yang 
bersangkutan hanya mempunyai kekuatan pembuktian sebagai akta di bawah tangan".

Dalam Undang-Undang Jabatan Notaris tidak diatur asas kehati-hatian dalam pembuatan akta. Namun peneliti berpendapat bahwa asas kehati-hatian dalam Undang-Undang Jabatan Notaris dapat diartikan dalam ketentuan Pasal 15 UUJN, sebagai berikut:

1. Notaris berwenang membuat akta autentik mengenai semua perbuatan, perjanjian, dan ketetapan yang diharuskan oleh peraturan perundangundangan dan/atau yang dikehendaki oleh yang berkepentingan untuk dinyatakan dalam akta autentik, menjamin kepastian tanggal pembuatan akta, menyimpan akta, memberikan grosse, salinan dan kutipan akta, semuanya itu sepanjang pembuatan akta-akta itu tidak juga ditugaskan atau dikecualikan kepada pejabat lain atau orang lain yang ditetapkan oleh undang-undang.

2. Notaris berwenang pula mengesahkan tanda tangan dan menetapkan kepastian tanggal surat di bawah tangan dengan mendaftar dalam buku khusus, membukukan surat-surat di bawah tangan dengan mendaftar dalam buku khusus, membuat Salinan dari asli surat-surat di bawah tangan berupa salinan yang memuat uraian sebagaimana ditulis dan digambarkan dalam surat yang bersangkutan, melakukan pengesahan kecocokan Salinan dengan surat aslinya, serta memberikan penyuluhan hukum sehubungan dengan pembuatan akta.

Terkait autentisitas akta yang di buat Notaris berdasarkan UndangUndang Jabatan Notaris bahwa Notaris wajib mengetahui identitas para penghadap serta meminta data pendukung yang berhubungan dengan akta yang akan dibuatnya seperti identitas para penghadap dan dokumen lain sebagaimana dipersyaratkan dalam pembuatan akta autentik. Hal ini sejalan dengan ketentuan Pasal 39 UUJN, dijelaskan sebagai berikut:

1. Penghadap harus memenuhi syarat sebagai berikut:

a. Paling sedikit berumur 18 (delapan belas) tahun atau telah menikah; dan

b. Cakap melakukan perbuatan hukum. 
2. Penghadap harus dikenal oleh Notaris atau diperkenalkan kepadanya oleh 2 (dua) orang saksi pengenal yang berumur paling sedikit 18 (delapan belas) tahun atau telah menikah dan cakap melakukan perbuatan hukum atau diperkenalkan oleh 2 (dua) penghadap lainnya;

3. Pengenalan sebagaimana dimaksud pada ayat (2) dinyatakan secara tegas dalam akta. Lebih lanjut, Pasal 40 UUJN menjelaskan, sebagai berikut:

a. Setiap akta yang dibacakan oleh Notaris dihadiri paling sedikit 2 (dua) orang saksi, kecuali peraturan perundang-undangan menentukan lain.

b. Saksi sebagaimana dimaksud pada ayat (1) harus memenuhi syarat sebagai berikut:

1) Paling sedikit berumur 18 (delapan belas) tahun atau telah menikah;

2) Cakap melakukan perbuatan hukum;

3) mengerti bahasa yang digunakan dalam akta;

4) Dapat membubuhkan tanda tangan dan paraf; dan

5) Tidak mempunyai hubungan perkawinan atau hubungan darah dalam garis lurus ke atas atau ke bawah tanpa pembatasan derajat dan garis ke samping sampai dengan derajat ketiga dengan Notaris atau para pihak.

c. Saksi sebagaimana dimaksud pada ayat (1) harus dikenal oleh Notaris atau diperkenalkan kepada Notaris atau diterangkan tentang identitas dan kewenangannya kepada Notaris oleh penghadap;

d. Pengenalan atau pernyataan tentang identitas dan kewenangan saksi dinyatakan secara tegas dalam akta.

Dalam hal ini, bentuk akta Notaris diatur berdasarkan ketentuan Pasal 38 UUJN yaitu sebagai berikut:

1. Setiap akta terdiri atas:
a. Awal akta/kepala akta;
b. Badan akta; dan
c. Akhir/penutup akta.

2. Awal akta/kepala akta memuat:

a. Judul akta;

b. Nomor akta; 
c. Jam, hari, tanggal, bulan, dan tahun;

d. Nama lengkap dan kedudukan Notaris.

3. Badan Akta memuat:

a. Nama lengkap, tempat dan tanggal lahir, kewarganegaraan, pekerjaan, jabatan, kedudukan, tempat tinggal para penghadap dan/atau orang yang mereka wakili;

b. Keterangan mengenai kedudukan bertindak penghadap;

c. Isi Akta yang merupakan kehendak dan keinginan dari pihak yang berkepentingan; dan

d. Nama lengkap, tempat dan tanggal lahir, serta pekerjaan, jabatan, kedudukan, dan tempat tinggal dari tiap-tiap saksi pengenal.

4. Akhir atau penutup akta, memuat:

a. Uraian tentang pembacaan Akta sebagaimana dimaksud dalam Pasal 16 ayat (1) huruf m atau Pasal 16 ayat (7);

b. Uraian tentang penandatanganan dan tempat penandatanganan atau penerjemahan Akta jika ada;

c. Nama lengkap, tempat dan tanggal lahir, pekerjaan, jabatan, kedudukan, dan tempat tinggal dari tiap-tiap saksi Akta;

d. Uraian tentang tidak adanya perubahan yang terjadi dalam pembuatan Akta atau uraian tentang adanya perubahan yang dapat berupa penambahan, pencoretan, atau penggantian serta jumlah perubahannya.

5. Akta Notaris Pengganti dan Pejabat Sementara Notaris, selain memuat ketentuan sebagaimana dimaksud pada ayat (2), ayat (3), dan ayat (4), juga memuat nomor dan tanggal penetapan pengangkatan, serta pejabat yang mengangkatnya.

Berdasarkan ketentuan pasal di atas, apabila persyaratan tersebut tidak dipenuhi maka akta notaris akan tidak memiliki kekuatan pembuktian secara autentik. Maka dari itu, upaya dalam mencegah pemalsuan indetitas penghadap terhadap akta yang dibuat Notaris harus sesuai dengan ketentuan bentuk akta yang diatur dalam UUJN. Demi menjaga prinsip kehati-hatian, dalm Pasal 70 huruf b Majelis Pengawas Daerah berwenang untuk melakukan pemeriksaan 
terhadap protokol notaris secara berkala 1 (satu) kali dalam 1 (satu) tahun atau setiap waktu yang dianggap perlu, berdasarkan pasal tersebut penulis beranggapan bahwa sebaiknya majelis pengawas melakukan pemeriksaan terhadap protokol notaris secara berkala baik 3 (tiga) bulan atau 6 (enam) bulan sekali. Pembentukan Majelis Pengawas untuk menyelamatkan kepentingan masyarakat dari kerugian yang diakibatkan oleh Notaris yang tidak bertanggung jawab dan menjaga citra dan kewibawaan lembaga Notariat serta melindungi nama baik kelompok profesi Notaris dari penilaian yang generaliris. Selain hal tersebut menurut penulis dengan adanya Majelis Pengawas, maka mempunyai dampak positif yaitu akan membentuk suatu "Peradilan Profesi Notaris" yang dijalankan oleh Majelis Pengawas di setiap tingkatan secara berjenjang selain yang sudah ada pada organisasi profesi notaris sendiri. Dengan adanya peradilan tersebut, maka akan memberikan perlindungan hukum dan jaminan kepada Notaris dalam menjalankan jabatannya secara profesional.

Namun, apabila keterangan yang disampaikan penghadap yang memuat keterangan palsu atau data yang diberikan kepada Notaris berisikan data palsu tanpa sepengetahuan Notaris, maka akta dan pengikatan yang dibuat dihadapan Notaris secara pembuktian formil itu mengandung kebenaran, namun fakta pemalsuan yang disampaikan penghadap bukan kewenangan dan tanggungjawab Notaris sehingga tidak dapat dibuktikan kebenaran materiil. Hal ini karena Notaris tidak dapat menjamin kebenaran bahwa pihak-pihak yang mempunyai kepentingan dalam pembuatan akta telah secara benar memberikan keterangan dan data-data. Dengan demikian, apabila terjadi masalah pemalsuan identitas yang dimuat dalam akta Notaris, maka Notaris tidak bertanggungjawab atas pemalsuan tersebut.

Terkait autentisitas akta yang di buat Notaris tidak berdasarkan asas kehati-hatian, maka secara pembuktian formil dan materil akta tersebut batal demi hukum sebagaimana dijelaskan dalam bab sebelumnya. Sejalan dengan pernyataan Sjaifurrachman, menjelaskan bahwa autentisitas akta hanya dapat tercipta apabila syarat-syarat formal atau syarat-syarat bentuk gebruik in de vorm 
yang ditentukan dalam Undang-Undang Jabatan Notaris terpenuhi dan autentisitas ini tidak ditentukan oleh peraturan perundang-undangan lainnya. ${ }^{13}$

Bahwa autentisitas akta yang dibuat Notaris yang melanggar asas kehatihatian akan berdampak pada kekuatan pembuktian sempurna dan mengikat terhadap akta autentik. Sejalan dengan pernyataan M. Yahya Harahap, menjelaskan bahwa autentisitas akta ditinjau dari segi hukum pembuktian tulisan maka akta memiliki fungsi sebagai formalitas kausa dan sebagai alat bukti sehingga fungsi tersebut akan batal secara hukum apabila akta yang dibuat Notaris tidak memiliki kekuatan pembuktian sempurna. ${ }^{14}$

Dalam Hukum perdata, akta autentik yang tidak memiliki pembuktian sempurna akan berdampak pada syarat-syarat sah nya akta tersebut. Adapun syarat-syarat kebatalan (nietieg) yang diatur dalam KUHPerdata dapat dibagi menjadi dua, sebagai berikut:

1. Melanggar ketentuan Pasal 1230 ayat 1 KUHPerdata (sepakat mereka yang mengikat diri). Pasal 1320 ayat 1 KUHPerdata menyatakan perjanjian adalah sah apabila diantara para pihak sepakat mengikatkan diri. Tiada sepakat yang sah (cacat kehendak). Dalam KUHPerdata terdapat tiga hal yang menjadi pembatalan perjanjian berdasarkan cacat kehendak, yaitu Kekhilafan, Paksaan dan Penipuan (Bedrog).

2. Melanggar syarat subyektif sahnya perjanjian, yaitu melanggar Pasal 1320 ayat 2 KUHPerdata (kecakapan membuat perjanjian). Melanggar Pasal 1320 ayat 2 KUHPerdata (Cakap bertindak menurut hukum), pasal ini menentukan bahwa perjanjian adalah sah apabila para pihak cakap dalam membuat suatu perjanjian.

\footnotetext{
${ }^{13}$ Sjaifurrachman dan Habib Adjie, Aspek Pertanggungjawaban Notaris Dalam Pembuatan Akta (Bandung: Mandar Maju: Bandung, 2011), hlm. 124.

${ }^{14}$ M. Yahya Harahap, Hukum Acara Perdata tentang Gugatan, Persidangan, Penyitaan, Pembuktian dan Putusan Pengadilan. (Jakarta: Sinar Grafika, 2008), hlm. 263.
} 
3. Melanggar ketentuan Pasal 1320 ayat 3 KUHPerdata (suatu hal tertentu). Suatu hal tertentu yang dimaksudkan adalah bahwa obyek perjanjian tersebut haruslah tertentu, dapat ditentukan yaitu suatu barang yang dapat diperdagangkan dan dapat dietentukan jenisnya secara jelas dan tidak kabur.

4. Melanggar ketentuan Pasal 1320 ayat 4 KUHPerdata (suatu sebab yang halal). Suatu sebab yang halal, apabila perjanjian itu dibuat berdasarkan kepada sebab yang sah dan dibenarkan oleh undangundang dan tidak melanggar ketentuan-ketentuan tentang isi dari perjanjian.

Lebih lanjut, akta yang tidak memilki kekuatan pembuktian, maka menyebabkan suatu perjanjian tidak memenuhi unsur-unsur keabsahan autentisitas akta sebagaimana ketentuan Pasal 1320 KUHPerdata. Sejalan dengan pernyataan Agus Yudha menjelaskan bahwa suatu perjanjian yang tidak memenuhi unsur-unsur keabsahan atau syarat sah terhadap suatu perikatan/perjanjian, maka baik syarat-syarat subyektif maupun obyektif akan mempunyai akibat-akibat sebagai berikut: ${ }^{15}$

1. "Noneksistensi" apabila tidak ada kesepakatan maka tidak timbul perjanjian;

2. "Vernietigbaar" atau dapat dibatalkan, apabila perjanjian tersebut lahir karena adanya cacat kehendak (wilsgebreke) atau karena ketidakcakapan (onbekwaamheid) Pasal 1320 syarat 1 dan 2, berarti hal ini terkait dengan syarat subyektif, sehingga berakibat kontrak itu dapat dibatalkan;

3. "Nietig" atau batal demi hukum, apabila terdapat perjanjian yang tidak memenuhi syarat obyek tertentu atau tidak mempunyai kausa atau kausanya tidak diperbolehkan (Pasal 1320 ayat 2 dan 4), berarti hal ini terkait dengan unsur-unsur obyektifnya, sehingga berakibat perjanjian tersebut batal demi hukum.

Selanjutnya dalam Pasal 1335 KUHPerdata ditegaskan bahwa, "Suatu perjanjian tanpa sebab, atau dibuat berdasarkan suatu sebab yang palsu atau

\footnotetext{
${ }^{15}$ Agus Yudha Hernoko, Hukum Pejanjian (Asas Proporsionalitas Dalam Kontrak Komersial) (Surabaya: Kencana, 2009), hlm. 160-161.
} 
yang terlarang, tidaklah mempunyai kekuatan". Adapun sebab yang diperbolehkan maksudnya adalah, bahwa apa yang hendak dicapai para pihak dalam perjanjian atau kontrak tersebut harus disertai etikat baik dan tidak bertentangan dengan peraturan perundangundangan, ketertiban umum, dan kesusilaan sesuai Pasal 1337 KUHPerdata. Dengan demikian, autentisitas akta yang dibuat Notaris dihubungkan dengan asas kehati-hatian dalam melaksanakan fungsi tugas dan kewenangan Notaris bahwa akta tersebut tidak dapat dikatakan akta autentik sebagaimana uraian di atas berdasarkan peraturan perundang-undangan, meskipun keterlibatan Notaris tidak dapat dimintai pertanggungjawaban atas perbuatanya karena pada dasarnya fungsi Notaris hanya sebatas menuangkan kehendak penghadap/para pihak berdasarkan kekuatan pembuktian formil, bukan memastikan kebenaran materil dari keterangan yang diberikan oleh penghadap/para pihak.

\section{Fungsi Notaris Dalam Pemeriksaan Identitas Penghadap Dihubungkan Dengan Tugas, Dan Wewenang Notaris Berdasarkan Undang-Undang Nomor 2 Tahun 2014 tentang Pembaharuan Atas Undang-Undang Nomor 30 Tahun 2004 tentang Jabatan Notaris}

Peran Notaris dalam bermasyarakat adalah sebagai pelayanan hukum kepada masyarakat secara mandiri dan tidak memihak dalam bidang kenotariatan. ${ }^{16}$ Bahwa peran Notaris adalah kepanjangan tangan Negara dimana ia menunaikan sebagian tugas negara dibidang hukum perdata dalam rangka memberikan perlindungan hukum dalam bidang hukum privat kepada warga Negara yang telah melimpahkan sebagaian wewenangnya kepada Notaris ${ }^{17}$.

Dalam memberikan pelayanan hukum, Notaris dituntut secara professional dan bertanggungjawab terhadap perbuatannya sebagaimana ketentuan Undang-Undang sehingga dapat menjamin kepastian dan

\footnotetext{
${ }^{16}$ Habib Adjie, Hukum Notaris Indonesia Tafsir Tematik Terhadap UU No 30. Tahun 2004 Tentang Jabatan Notaris (Bandung: Refika Aditama 2008), hlm. 13.

${ }^{17}$ Dody Radjasa Waluyo, Kewenangan Notaris Selaku Pejabat Umum (Jakarta: Media Notariat, 2001), hlm. 63 .
} 
perlindungan hukum kepada masyarakat yang membutuhkan jasa Notaris. Dalam Undang-Undang Nomor 2 Tahun 2014 tentang Perubahan Atas UndangUndang Nomor 30 Tahun 2004 tentang Jabatan Notaris menjelaskan bahwa Notaris adalah pejabat umum yang berwenang untuk membuat akta autentik dan memiliki kewenangan lainnya sebagaimana dimaksud dalam Undang-Undang ini atau berdasarkan undang-undang lainnya ${ }^{18}$. Pasal 1 Dalam Peraturan Menteri Hukum Dan Hak Asasi Manusia Nomor 9 Tahun 2017 tentang Penerapan Prinsip Mengenal Pengguna Jasa Bagi Notaris yaitu:

"Notaris adalah pejabat umum yang berwenang untuk membuat akta autentik dan memiliki kewenangan lainnya sebagaimana dimaksud dalam Undang-Undang Jabatan Notaris atau berdasarkan Undang-Undang lainnya".

Dalam Pasal 2 Permenkumham No. 9 Tahun 2017 mengenai Prinsip Mengenali Pengguna Jasa Notaris disebutkan bahwa notaris wajib menerapkan prinsip mengenali Pengguna Jasa yang paling sedikit memuat identifikasi Pengguna Jasa, verifikasi Pengguna Jasa dan pemantauan Transaksi Pengguna Jasa. ${ }^{19}$ Penerapan ini berlaku bagi notaris dalam memberikan jasa berupa mempersiapkan dan melakukan transaksi untuk kepentingan atau untuk dan atas nama Pengguna Jasa, mengenai pembelian dan penjualan properti, pengelolaan terhadap uang, efek, dan/atau produk jasa keuangan lainnya, pengelolaan rekening giro, rekening tabungan, rekening deposito, dan/atau rekening efek, pengoperasian dan pengelolaan perusahaan; dan/atau pendirian, pembelian, dan penjualan badan hukum.

Notaris sebagai perjabat umum yang berfungsi membuat akta autentik dihubungkan dengan tugas dan kewenangannya dalam UUJN, bahwa Notaris

\footnotetext{
${ }^{18}$ Ibid, Pasal 1 angka (1).

${ }^{19}$ Helmi Fariska Rahma, Tanggung Jawab Dan Akibat Hukum Notaris Dalam Melakukan Identifikasi Dan Verifikasi Data Pengguna Jasa Dalam Peraturan Menteri Hukum Dan Hak Asasi Manusia Nomor 9 Tahun 2017, (Tesis Program Magister Kenotariatan Universitas Islam Indonesia Yogyakarta, 2018), hlm. 83-86.
} 
bertugas dan berwenang membuat akta autentik mengenai semua perbuatan, perjanjian, dan ketetapan yang diharuskan oleh peraturan perundang-undangan dan/atau yang dikehendaki oleh yang berkepentingan untuk dinyatakan dalam akta autentik, menjamin kepastian tanggal pembuatan akta, menyimpan akta, memberikan grosse, salinan dan kutipan akta, semuanya itu sepanjang pembuatan akta-akta itu tidak juga ditugaskan atau dikecualikan kepada pejabat lain atau orang lain yang ditetapkan oleh undang-undang. ${ }^{20}$

Notaris juga bertugas dan berwenang mengesahkan tanda tangan dan menetapkan kepastian tanggal surat di bawah tangan dengan mendaftar dalam buku khusus, membukukan surat di bawah tangan dengan mendaftar dalam buku khusus, membuat kopi dari asli surat di bawah tangan berupa salinan yang memuat uraian sebagaimana ditulis dan digambarkan dalam surat yang bersangkutan, melakukan pengesahan kecocokan fotokopi dengan surat aslinya, memberikan penyuluhan hukum sehubungan dengan pembuatan Akta, membuat Akta yang berkaitan dengan pertanahan, atau membuat Akta risalah lelang. ${ }^{21}$

Bahwa peran Notaris dihubungkan dengan fungsi, tugas dan kewenangannya berdasarkan UUJN adalah melayani masyarakat (para pihak) yang membutuhkan alat bukti tertulis yang bersifat autentik mengenai peristiwa dan/atau perbuatan hukum yang dikehendaki berdasarkan peraturan perundang-undangan bahwa tindakan hukum tertentu wajib dibuat dalam bentuk akta autentik. Sejalan dengan pernyataan Liliana Tedjosaputro menjelaskan bahwa Notaris sebagai pembuat akta autentik berdasarkan UUJN merupakan lembaga yang ada dalam masyarakat dan timbul karena adanya kebutuhan anggota masyarakat yang melakukan tugas dan kewenangan terhadap suatu perbuatan hukum yang menghendaki adanya suatu alat bukti

\footnotetext{
${ }^{20}$ Ibid, Pasal 15 ayat (1).

${ }^{21}$ Ibid, Pasal 15 ayat (2).
} 
tertulis jika ada sengketa atau permasalahan agar dapat dijadikan bukti yang paling kuat dipengadilan. ${ }^{22}$

Dalam penelusuran peneliti terkait praktik Notaris terkait pemeriksaan identitas penghadap terhadap autentisitas akta dengan asas kehati-hatian, bahwa Notaris melakukan pengenalan penghadap untuk mengetahui penghadap adalah pihak yang cakap dan berwenang berdasarkan aturan hukum pembuatan akta, memastikan kebenaran identitas penghadap berdasarkan yang diperlihatkan Notaris, memastikan Surat/Dokumen yang dilampirkan terkait objek perjanjian adalah benar keaslian dan keabsahan, dan membuat akta sesuai dengan ketentuan perundang-undangan tanpa adanya unsur memalsukan keterangan yang dimuat dalam akta guna menjamin kebenaran formil akta yang dibuatnya.

Demi tercapainya prinsip kehati-hatian Notaris dalam mengenal para penghadap. Jika terdapat keraguan dan kesalahan atas dokumen-dokumen para penghadap Notaris sebaiknya menolak untuk membuat akta otentik, untuk tercapainya prinsip kehati-hatian mengenal para penghadap dan tidak menjadi sengketa dikemudian hari.

Peraturan Menteri Hukum Dan Hak Asasi Manusia Nomor 9 Tahun 2017 tentang Penerapan Prinsip Mengenali Penguna Jasa Bagi Notaris, mewajibkan Notaris menerapkan prinsip mengenali jasa pengguna jasanya, Pasal 2 ayat (2) yaitu:

1. Identifikasi Pengguna Jasa;

2. Verifikasi Pengguna Jasa;

3. Pemantauan Transaksi Pengguna Jasa.

Pasal 2 ayat (4) Notaris Wajib melaporkan ke PPATK, yaitu:

1. Melakukan hubungan usaha dengan pengguna jasa;

\footnotetext{
${ }^{22}$ Liliana Tedjosaputro, Etika Profesi Notaris: Dalam Penegakan Hukum Pidana (Yogyakarta: Bigraf Publishing, 1995), hlm. 84.
} 
2. Terdapat Transaksi Keuangan dengan mata uang rupiah dan/atau mata uang asing yang nilainya paling sedikit atau setara dengan Rp.100.000.000.00 (seratus juta rupiah);

3. Terdapat transaksi keuangan mencurigakan yang terkait tindak pidana Pencucian Uang dan Tindak pidana pendanaan terorisme; atau

4. Notaris meragukan kebenaran informasi yang dilaporkan Pengguna Jasa.

Menurut Pasal 54 ayat (2) Peraturan Kepala Badan Pertanahan Nasional RI (Perkaban) Nomor 1 Tahun 2006 sebagaimana telah diubah dan ditambah dengan Perkaban Nomor 23 Tahun 2009 Tentang Ketentuan Pelaksanaan Peraturan Pemerintah Nomor 37 Tahun 1998 Tentang Peraturan Jabatan Pejabat Pembuat Akta Tanah (PPAT), menjelaskan bahwa tidak diperbolehkan memuat kata-kata "sesuai atau menurut keterangan para pihak" kecuali didukung oleh data formil. Lebih lanjut, Pasal 54 Ayat (3) menjelaskan bahwa dan PPAT/Notaris berwenang menolak pembuatan akta, yang tidak didasari data formil. ${ }^{23}$

Pembuktian formil yang dimaksud di atas yakni pembuktian terhadap identitas dan kelengkapan Surat/Dokumen yang dilampirkan terkait objek perjanjian dalam pembuatan akta yang sesuai dengan database Dinas/Instansi terkait. Selain itu, kebenaran formil juga meliputi kebenaran Kartu Tanda Penduduk (KTP), Surat Nikah, Surat Kuasa, Surat Persetujuan Istri/Suami, Perjanjian Kawin, Anggaran Dasar Perseroan dan perubahanperubahannya), meminta Nomor Pokok Wajib Pajak (NPWP), meminta Surat Pernyataan tidak dalam sengketa mengenai objek perbuatan hukum baik secara fisik maupun secara yuridis, meminta Surat Ijin dari Pejabat yang berwenang dalam hal pengalihan atau pembebanan objek dalam perbuatan hukum, meminta bukti

\footnotetext{
${ }^{23}$ Peraturan Kepala Badan Pertanahan Nasional RI (Perkaban) Nomor 1 Tahun 2006 sebagaimana telah diubah dan ditambah dengan Perkaban Nomor 23 Tahun 2009 Tentang Ketentuan Pelaksanaan Peraturan Pemerintah Nomor 37 Tahun 1998 Tentang Peraturan Jabatan Pejabat Pembuat Akta Tanah (PPAT).
} 
pembayaran lunas pajak PPN dan BPHTB terkait pembuatan Akta Jual Beli Tanah, meminta dilakukan pengukuran lebih dahulu oleh Kantor Pertanahan setempat dan diterbitkan NIB (Nomor Identifikasi Bidang Tanah) dari tanah tersebut serta mencantumkan NIB, Nomor Sertipikat dan Nomor SPPT PBB

\section{PENUTUP}

1. Autentisitas akta yang dibuat Notaris dihubungkan dengan asas kehatihatian dalam pelaksanaan fungsi Notaris telah memenuhi unsur pembuktian formil akta sebagai upaya penerapan asas kehati-hatian dengan cara memastikan bahwa akta yang dibuat notaris sesuai dengan tugas dan wewenang Notaris yang diatur dalam UUJN dan sesuai dengan hukum pembuktian perjanjian dan syarat-syarat sahnya suatu perjanjian, yang secara keseluruhan memenuhi unsur esensial terpenuhinya formal suatu akta meliputi pembuatan akta berdasarkan Undang-Undang, dibuat dihadapan Pejabat Umum.

2. Fungsi Notaris dalam pemeriksaan identitas penghadap dihubungkan dengan tugas dan wewenang Notaris berdasarkan UUJN yakni Notaris harus memastikan identitas penghadap telah memenuhi syarat-syarat pembuatan akta autentik berdasarkan Pasal 39 dan Pasal 40 UUJN dengan cara melakukan pengenalan penghadap, memastikan kebenaran (valid) identitas penghadap, dan membuat akta autentik berdasarkan UUJN. Apabila terdapat unsur pemalsuan identitas penghadap yang dimuat dalam akta, maka akta yang dibuat Notaris harus mempunyai kekuatan pembuktian sebagai akta di bawah tangan sebagaimana ketentuan Pasal 41 UUJN, sehingga dalam menjalankan fungsinya bahwa Notaris harus cermat dan teliti dalam memeriksa identitas penghadap sebagaimana pengertian "seksama" yang dimaksudkan dalam Pasal 16 ayat (1) huruf (a) UUJN, serta ditindaklanjuti dalam Pasal 2 ayat (2) Peraturan Menteri Hukum dan Hak Asasi Manusia Nomor 9 Tahun 2017 tentang Penerapan Prinsip Mengenali Pengguna Jasa Bagi Notaris. 
Syiar Hukum Jurnal Ilmu Hukum | Volume 18 Nomor 2 


\section{DAFTAR PUSTAKA}

\section{A. Buku}

Agus Yudha Hernoko, Hukum Pejanjian. Asas Proporsionalitas Dalam Kontrak Komersial. Surabaya: Kencana, 2009.

Dody Radjasa Waluyo. Kewenangan Notaris Selaku Pejabat Umum. Jakarta: Media Notariat, 2001.

Freddy Haris \& Leny Helena, Notaris Indonesia. Jakarta: Lintas Cetak Publishig, 2017.

Habib Adjie. Hukum Notaris Indonesia Tafsir Tematik Terhadap UU No 30. Tahun 2004 Tentang Jabatan Notaris. Bandung: Refika Aditama 2008.

Hartanti Silihandari \& Nisya Rifiani. Prinsip-Prinsip Dasar Profesi Notaris. Yogyakarta: Dunia Cerdas, 2013.

Irwan Soerodjo. Kepastian Hukum Hak Atas Tanah di Indonesia. Surabaya: Arkola, 2003.

Liliana Tedjosaputro. Etika Profesi Notaris: Dalam Penegakan Hukum Pidana. Yogyakarta: Bigraf Publishing, 1995.

M. Yahya Harahap. Hukum Acara Perdata tentang Gugatan, Persidangan, Penyitaan, Pembuktian dan Putusan Pengadilan. Jakarta: Sinar Grafika, 2008.

M. Luthfan Hadi Darus. Hukum Notariat dan Tanggung Jawab Jabatan Notaris. Yogyakarta: UII Press, 2017.

M. Lutfan Hadi Darus. Hukum Notariat dan Tanggung jawab Jabatan Notaris. Yogyakarta: UII Press, 2017.

Sjaifurrachman dan Habib Adjie. Aspek Pertanggungjawaban Notaris Dalam Pembuatan Akta. Mandar Maju: Bandung, Tahun 2011.

\section{B. Jurnal/Tesis}

Helmi Fariska Rahma. Tanggung Jawab Dan Akibat Hukum Notaris Dalam Melakukan Identifikasi Dan Verifikasi Data Pengguna Jasa Dalam Peraturan Menteri Hukum Dan Hak Asasi Manusia Nomor 9 Tahun 2017. Tesis Program Magister Kenotariatan Universitas Islam Indonesia Yogyakarta, 2018.

Rahaman, Fikri A. Penerapan Prinsip Kehati-hatian Notaris dalam Mengenal para Penghadap. Tesis, Universitas Islam Bandung, 2018. 
Rahmad Hendra. Tanggung Jawab Notaris Terhadap Akta Autentik yang Penghadapnya Mempergunakan Identitas Palsu. Jurnal Ilmu Hukum, vol. 2, no. 2. Universitas Riau, Kota Pekanbaru, 2012.

\section{Peraturan Perundang-Undangan}

\section{Undang-Undang Dasar 1945}

Ketentuan Hukum Acara Perdata (KUHPerdata).

Ketentuan Hukum Acara Pidana (KUHPidana)

Kode Etik Notaris Ikatan Notaris Indonesia (I.N.I). Banten. Tahun 2015.

Peraturan Menteri Hukum dan Hak Asasi Manusia Nomor 9 Tahun 2017 tentang Penerapan Prinsip Mengenali Pengguna Jasa Bagi Notaris.

Peraturan Kepala Badan Pertanahan Nasional RI (Perkaban) Nomor 1 Tahun 2006 sebagaimana telah diubah dan ditambah dengan Perkaban Nomor 23 Tahun 2009 Tentang Ketentuan Pelaksanaan Peraturan Pemerintah Nomor 37 Tahun 1998 Tentang Peraturan Jabatan Pejabat Pembuat Akta Tanah (PPAT).

Undang-Undang Nomor 2 Tahun 2014 tentang Pembaharuan Atas Undang-Undang Nomor 30 Tahun 2004 tentang Jabatan Notaris. 